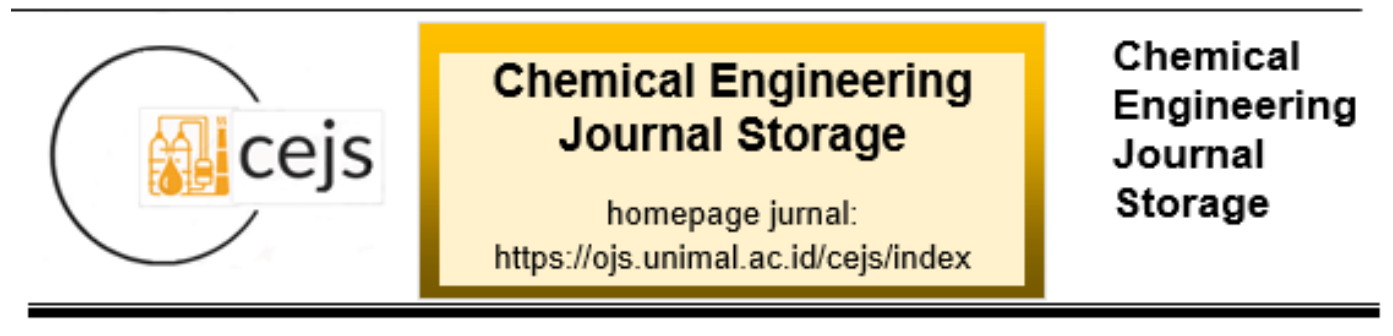

\title{
PEMANFAATAN BUAH BELIMBING WULUH (AVERHOA BLIMBI.L) SEBAGAI PENGAWET DALAM PEMBUATAN SAUS SAMBAL
}

\author{
R.A Nita Rosalinda ${ }^{1}$, Suryati ${ }^{1}$, Masrulita ${ }^{1}$, Novi Sylvia ${ }^{1}$, Meriatna ${ }^{1}$ \\ ${ }^{1}$ Jurusan Teknik Kimia, Fakultas Teknik, Universitas Malikussaleh \\ Kampus Utama Cot Teungku Nie Reuleut, Muara Batu, Aceh Utara - 24355 \\ Korespondensi: HP: 081269034134, *e-mail: suryati@unimal.ac.id
}

\begin{abstract}
Abstrak
Saus adalah gabungan dari beberapa bahan yang diolah baik dari bahan utama maupun bahan tambahan lainnya yang dicampurkan, Sehingga didapatkan nya sebuah poduk dalam berbentuk cairan yang kental, bahan-bahan yang digunakan dalam pembuatan saus sambal antara lain cabe merah segar, bawang putih, garam, tomat, gula, asam cuka, air dan bahan pengental seperti tepung maizena. Sedangkan bahan tambahan lain yang digunakan sebagai bahan pembantu dalam pembuatan saus sambal ini yaitu: belimbing wuluh sebagai pengawet alami, labu kuning sebagai bahan yang meningkatkan volume dari hasil olahan saus, wortel sebagai pewarna dalam kategori alami, dan Penelitian ini dilakukan selama 3 bulan, dalam pembuatan saus sambal, buah belimbing wuluh yang dipakai ada dua jenis yaitu buah belimbing wuluh yang masih segar dan buah belimbing wuluh yang sudah dijemur atau dikeringkan (belimbing wuluh kering). Untuk mengetahui pengaruh penambahan buah belimbing wuluh dan berapa lama umur daya simpan saus sambal tersebut, maka diperlukan analisa kadar air, analisa derajat keasaman ( $p H)$, analisa viskositas, analisa jamur (angka kapang dan khamir) dan analisa bakteri (angka lempeng total). Jenis pengawet yang memliki kandungan kadar air terbaik terdapat pada buah belimbing wuluh segar dengan massa 80 gram sebesar 49,87\%. Jumlah derajat keasaman $(\mathrm{pH})$ terbaik terdapat pada buah belimbing wuluh segar dengan massa 80 gram yakni 3,21. Perlakuan terbaik pada analisa angka kapang dan khamir yakni pada buah belimbing wuluh kering dengan massa 80 gram yaitu sebanyak 1 koloni/gr
\end{abstract}

Kata Kunci: Angka kapang dan Khamir, Angka lempeng total, Belimbing wuluh segar, Belimbing wuluh kering dan Kadar air.

\section{Pendahuluan}

Pecinta makanan pedas selalu mengharapkan adanya cabai pada setiap jenis makanan yang dikonsumsi, akan tetapi membawa cabai utuh setiap saat merupakan 
hal yang tidak mudah. Seiring dengan kemajuan teknologi pengolahan pangan, cabai dapat diolah menjadi produk yang lebih praktis. Salah satu olahan cabai yang digemari masyarakat yaitu saus cabai. Saus dalam istilah masak memasak berarti cairan kental yang digunakan sewaktu memasak atau dihidangkan bersama makanan sebagai penyedap atau agar makanan kelihatan bagus. Saus juga dapat diartikan sebagai cairan kental (pasta) yang terbuat dari bubur buah berwarna menarik biasanya merah. Saus merupakan salah satu produk olahan pangan yang sangat populer. Saus tidak saja hadir dalam sajian seperti mie bakso atau mie ayam, tetapi juga dijadikan bahan pelengkap nasi goreng, mie goreng dan aneka makanan fast food.

Saus cabai merupakan salah satu bahan penyedap masakan dan penambah cita rasa pada makanan. Bahan baku utama saus cabai adalah cabai, selain itu ditambahkan pula bahan-bahan lain seperti bahan pengganti,bumbu, pengawet, dan pengasam. Masing-masing bahan tersebut mempunyai fungsi tersendiri. Sebagai produk yang berfungsi sebagai penyedap dan penambah citarasa, maka rasa menjadi faktor yang penting.

Berdasarkan Standar Nasional Indonesia (SNI) No. 01-2976 tahun 2006, saus cabai adalah saus yang diperoleh dari bahan utama cabai (Capsicum Sp), baik yang diolah dengan penambahan bumbu-bumbu dengan atau tanpa penambahan bahan makanan lain dengan bahan tambahan pangan yang diizinkan. Ramai nya minat kebutuhan pasar akan saus mengakibatkan banyaknya industri berkembang yang memproduksi saus, namun tidak semua yang berlaku jujur seperti dengan penambahan bahan pengawet yang berbahaya atau pemberian bahan pengawet yang tidak sesuai dengan takaran yang dianjurkan. Dengan begitu, hal ini dapat menyebabkan gangguan kesehatan bagi yang mengkonsumsinya. Pengawet adalah bahan tambahan pangan untuk mencegah atau menghambat fermentasi, pengasaman atau peruraian lain terhadap pangan yang disebabkan oleh mikroorganisme. Bahan pengawet biasanya digunakan untuk mengawetkan bahan pangan yang mudah rusak dan memilki fungsi untuk menjaga nutrisi makanan dan menambah daya simpan pangan. Bahan pengawet yang sering digunakan pada pembuatan saus sambal adalah natrium benzoat, Natrium 
benzoat $\left(\mathrm{C}_{7} \mathrm{H}_{5} \mathrm{O}_{2} \mathrm{Na}\right)$ adalah garam natrium yang digunakan untuk menghambat pertumbuhan mikroorganisme karena kelarutannya lebih baik daripada bentuk yang lain. Selain kelarutan nya yang baik, Natrium Benzoat memiliki kekurangan dari segi kesehatan, penggunaan pengawet Natrium benzoat dalam jangka panjang dapat menimbulkan penyakit Lupus (Sytemic Lupus Eritematosus/SLE), dapat menimbulkan reaksi alergi dan penyakit saraf, dan bila terakumulasi dalam tubuh dengan jumlah yang besar maka akan memicu tumbuhnya sel kanker.

Belimbing wuluh memang bukan buah yang bisa disantap sebagai buah segar apalagi sampai dipajang di meja makan. Buah belimbing wuluh (Averhoa bilimbi L) mengandung senyawa kimia yaitu asam format, asam sitrat, asam askorbat (Vitamin C), saponin, tanin, glukosid, flavonoid, dan beberapa mineral terutama kalsium dan kalium dalam bentuk kalium sitrat dan kalium oksalat. Sifat kimiawi nya rasa asam dan bersifat sejuk. Berkhasiat menghilangkan rasa sakit, memperbanyak pengeluaran empedu, anti radang, peluruh kencing, astrigen, mengobati hipertensi, batuk rejan, sariawan, pegal linu, gondongan, rematik, jerawat, dan panu. Kandungan zat gizi yang ada pada belimbing wuluh cukup banyak sehingga bila tidak dimanfaatkan dengan baik akan sia-sia serta dibuang dengan percuma.

Melihat banyaknya manfaat dari buah belimbing wuluh ini, mendorong penulis untuk melakukan penelitian membuat saus sambal dengan menggunakan pengawet alami yaitu pengawet dari belimbing wuluh, penggunaan buah belimbing wuluh menjadi bahan penyedap makanan seperti saus dan pasta belum populer di masyarakat luas. Namun di beberapa daerah penghasil buah belimbing, pengolahan buah belimbing menjadi saus sudah dilakukan. Senyawa asam format yang terdapat dalam buah belimbing wuluh dapat dijadikan sebagai bahan pengawet untuk menghambat enzim anti mikroba dan memilki banyak manfaat dari segi kesehatan. Tekstur saus belimbing sangat mirip dengan saus tomat yang umumnya dipasaran, namun aroma dan rasanya sangat jauh berbeda. Pemilihan dan pengolahan sangat mempengaruhi kualitas dari saus belimbing. Biasanya produsen menggunakan buah belimbing matang fisiologis pada saat pengolahan (Hes, 2013). 
Tingkat keawetan saus cabai sangat ditentukan oleh proses pengolahan yang diterapkan dan jumlah bahan pengawet yang digunakan. Jika proses pengolahan dilakukan secara benar, dengan sendirinya produk menjadi awet, sehingga tidak diperlukan bahan pengawet yang berlebih.

\section{Bahan dan Metode}

Adapun bahan yang digunakan dalam penelitian ini adalah cabe merah segar 500 gram, bawang putih 250 gram, tomat, 250 gram, gula 100 gram, garam 25 gram, asam cuka $50 \mathrm{ml}$, air $70 \mathrm{ml}$ dan bahan pengental seperti tepung maizena sebanyak 25 gram. Sedangkan bahan tambahan lain yang digunakan sebagai bahan pembantu dalam pembuatan saus sambal ini antara lain, belimbing wuluh sebagai pengawet alami sebanyak 400 gram, labu kuning sebagai bahan yang meningkatkan volume dari hasil olahan saus sebesar 1000 gram, wortel sebagai pewarna dalam kategori alami sebanyak 750 gram. Kemudian bahan lain yang digunakan yaitu potato dextrose agar dan plate count agar untuk analisa angka kapang dan khamir dan analisa angka lempeng total. Peralatan penelitian yang digunakan dalam penelitian ini adalah wadah plastik, sendok, kompor gas, panci, blender, saringan/ayakan, timbangan digital, thermometer, cawan petri, labu ukur, pipet volumetric, beaker glass, erlenmeyer spatula, tabung reaksi, tisu steril, kertas HVS steril dan botol saus.

Penelitian ini terdiri dari tiga tahap, dimana tahap yang pertama yaitu memilih bahan baku yang berkualitas dan layak untuk digunakan. Bahan yang sudah dipilih kemudian dibersihkan dengan cara dicuci. Pencucian dilakukan untuk membersihkan atau menghilangkan kotoran yang masih menempel pada bahan, baik berupa debu, getah, lendir, noda, mikroba, dan sebagainya.

Tahap kedua yang dilakukan yaitu tahap persiapan pembuatan pengawet menggunakan belimbing wuluh. Buah belimbing wuluh yang dipakai dalam penelitian ini ada dua, diantara nya yaitu: buah belimbing wuluh segar dan buah belimbing wuluh yang dikeringkan. Untuk proses pembuatan menggunakan belimbing segar, belimbing nya dapat langsung di tambahkan kedalam saus sambal, 
dalam keadaan sudah digiling. Sedangkan untuk proses menggunakan belimbing kering, perlu dilakukan nya proses pengeringan, dan ditambahkan dalam keadaan yang sudah digiling juga.

Setelah bahan-bahan yang diperlukan sudah dipersiapkan, dilanjutkan pada tahap pembuatan saus sambal yang diawali dengan penimbangan bahan sesuai dengan variabel yang telah ditentukan, kemudian bahan-bahan tersebut dikukus atau di blanshing yang tujuan nya untuk membuat tekstur bahan yang dikukus menjadi lebih lunak sehingga memudahkan proses penggilingan dan proses pengukusan dilakukan selama 10 menit pada suhu $100^{\circ} \mathrm{C}$. Setelah pengukusan selesai bahan didiamkan dari kedaan panas sampai ke dalam keadaan dingin, supaya bahan bisa dimasukkan ke blender. Setelah bahan tersebut sudah dalam keadaan dingin, masukkan bahan-bahan ke dalam blender, kemudian bahan digiling sampai benarbenar halus. Penggilingan dilakukan sampai diperoleh bubur saus dengan warna dan kehalusan yang merata. Setelah Proses penggilingan, saring saus kedalam ayakan supaya dapat dipisahkan antara saus sambal mentah dengan biji-biji cabai yang tidak hancur saat penggilingan. Adonan saus yang sudah disaring dimasak di atas kompor dengan menggunakan wajan selama 20 menit sampai suhu $100^{\circ} \mathrm{C}$ atau sampai bubur saus mendidih. Dimasak saus sambal, kemudian ditambahkan bahan seperti gula, garam dan cuka lalu diaduk sebentar sampai terbentuk gelembung pada saus. Pengadukan dilakukan terus menerus secara perlahan kemudian ditambahkan tepung maizena yang sudah dicairkan sambil terus diaduk. Setelah diperoleh kekentalan yang diinginkan, dimatikan kompor. Lalu saus sambal dituangkan ke dalam wadah yang lain.

Diambil saus sambal sebanyak 100 gram, lalu diberi penambahan pengawet belimbing wuluh segar/belimbing wuluh kering sesuai dengan variabel yang telah ditetapkan, yaitu 20 gram, 40 gram, 60 gram dan 80 gram. Penambahan buah belimbing wuluh sebagai pengawet dimasak dengan api yang sangat kecil untuk mempertahankankan bahan tetap panas sambil diaduk perlahan hingga saus sambal 
mengental kembali. Dimasukkan saus sambal ke dalam botol yang sudah disterilisasikan menggunakan corong kemudian ditutup, lalu diberi label.

Pengujian kadar air perlu dilakukan supaya saus sambal dapat bertahan lama jika tidak banyak terkandung air nya, sampel ditimbang sebanyak 2 gram. Kemudian dimasukkan ke dalam cawan petri yang telah diketahui beratnya. Bahan dikeringkan pada oven pada suhu $100-105^{\circ} \mathrm{C}$ selama 3-5 jam, selanjutnya didinginkan dalam desikator dan ditimbang beratnya. Bahan kemudian dikeringkan dalam oven (Froilabo, Japan) selama 30 menit didinginkan kemudian ditimbang dengan menggunakan timbangan analitik (Cheetah, China). Perlakuan ini diulangi sampai diperoleh berat yang konstan. Selanjutnya kadar air dihitung dengan menggunakan rumus.

Pengukuran $\mathrm{pH}$ dilakukan untuk mengetahui derajat keasaman saus sambal dengan menggunakan $\mathrm{pH}$ meter. Pengukuran $\mathrm{pH}$ diawali dengan $\mathrm{pH}$ meter dikalibrasi terlebih dahulu menggunakan larutan buffer. Sampel diambil sebanyak $50 \mathrm{ml}$ dan diaduk hingga merata. $\mathrm{pH}$ diketahui dengan membaca angka yang ditunjukkan pada alat. Nilai pH yang dipersyaratkan untuk saus cabai maksimal 4 (SNI 2006). Dengan demikian, produk saus sambal digolongkan sebagai bahan pangan asam. Penambahan asam berfungsi untuk menghambat pertumbuhan mikroba terutama bakteri, sehingga produk akan menjadi lebih awet.

Dalam mengetahui apakah pengawet tersebut layak atau tidak nya digunakan sebagai pengawet yang ditinjau dalam segi adanya pertumbuhan mikroba seperti jamur atau bakteri dan seberapa lama daya simpan umur saus sambal tersebut tanpa mengalami kerusakan, maka perlu dilakukan nya analisa mikroba seperti angka kapang dan khamir dan angka lempeng total. Disiapkan alat yang akan digunakan, kemudian di sterilisasi. Setelah bahan analisa yang digunakan sudah steril, kemudian media dimasak. Untuk analisa angka lempeng total dan analisa kapang dan khamir memiliki cara kerja yang sama yang membedakan nya hanya media nya saja. Untuk tahap analisa angka lempeng total media yang digunakan yaitu media PCA (plate 
count agar) sedangkan untuk tahap analisa kapang dan khamir media yang digunakan selama tahap analisa yaitu media PDA (potato dextrose agar).

\section{Hasil dan Diskusi}

Adapun hasil penelitian yang telah dilakukan menunjukkan bahwa pemanfaatan buah belimbing wuluh (averhoa blimbi.l) sebagai pengawet dalam pembuatan saus sambal memberikan pengaruh yang berbeda setiap bulan nya terhadap kadar air (\%), derajat keasaman $(\mathrm{pH})$, angka kapang dan khamir (koloni/g) dan angka lempeng total (CFU/g).

\subsection{Analisa Kadar Air}

Dari analisa kadar air yang telah dilakukan menggunakan pengawet belimbing segar dan belimbing kering, jenis pengawet yang memiliki kandungan kadar air tertinggi terdapat pada buah belimbing wuluh segar pada bulan ketiga dengan massa belimbing segar sebesar 20 gram yaitu $68,51 \%$, sedangkan kadar air terendah terdapat pada bulan pertama dengan massa belimbing segar sebesar 80 gram yaitu $49,78 \%$.

Adapun hubungan pengawet terhadap kadar air yang tertinggi dan terendah pada saus sambal dapat dilihat pada grafik 3.1 berikut

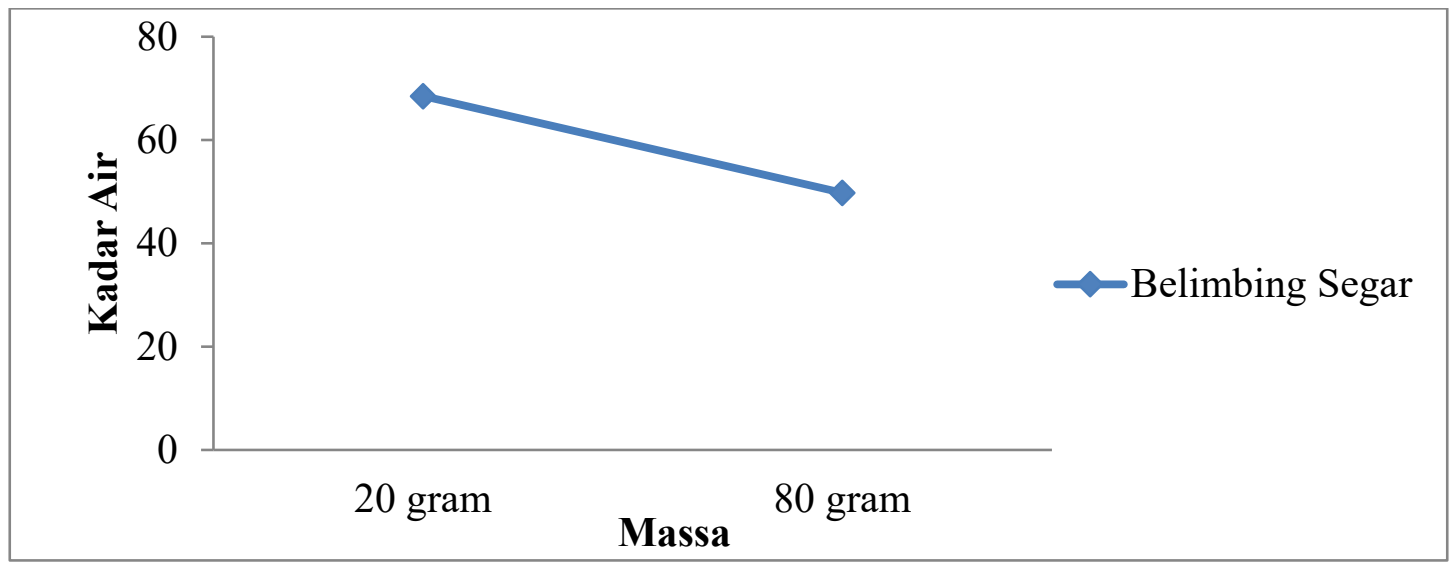

Gambar 3.1 Grafik hubungan kadar air dengan pengawet buah belimbing

Semakin sedikit buah belimbing atau semakin banyak labu kuning yang ditambahkan maka kadar air saus belimbing akan semakin tinggi. Hal ini sesuai pernyataan Departemen Kesehatan RI (1972) bahwa kadar air bahan baku labu kuning 91,2\%, lebih tinggi dibandingkan dengan belimbing 90\%. Menurut 
Andarwulan, dkk., $\left(20^{10}\right)$ kadar air meningkat karena proses pengukusan labu kuning. Air yang meresap dalam bubur merupakan air teradsorbsi lalu air tersebut terserap pada permukaan koloid makromolekul (protein dan pati) labu kuning sehingga semakin banyak proporsi labu kuning maka semakin tinggi kadar air saus belimbing.

\subsection{Analisa Derajat Keasaman (pH)}

Jumlah derajat keasaman $(\mathrm{pH})$ yang dimiliki bahan pengawet sangat berpengaruh pada kualitas saus yang akan dibuat. Dari analisa derajat keasaman $(\mathrm{pH})$ yang telah dilakukan menggunakan pengawet belimbing segar dan belimbing kering, jumlah derajat keasaman tertinggi terdapat pada massa belimbing segar sebesar 20 gram pada bulan ketiga yaitu 3,64, sedangkan derajat keasaman terendah terdapat pada bulan pertama dengan massa belimbing segar sebesar 80 gram yaitu 3,21.

Adapun hubungan pengawet terhadap derajat keasaman $(\mathrm{pH})$ yang tertinggi pada saus sambal dapat dilihat pada grafik 3.2 berikut.

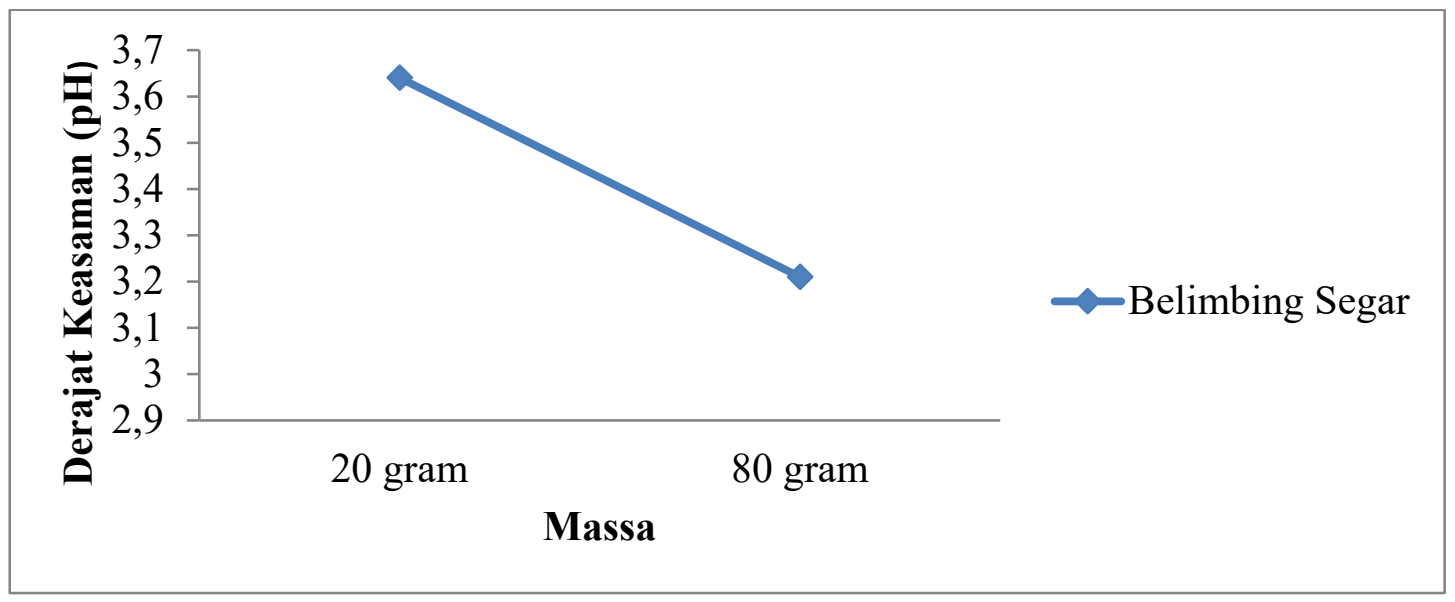

Gambar 3.2 Grafik hubungan pH dengan pengawet buah belimbing

Semakin sedikit buah belimbing yang digunakan maka derajat keasaman saus belimbing akan semakin meningkat. Ini dikarenakan karena buah belimbing mengandung asam oksalat, asam askorbat, asam formiat dan asam sitrat sehingga derajat keasaman akan semakin meningkat atau semakin basa. 
Hal ini sesuai dengan pernyataan Hasyim, dkk., (2011) dan Mursito (2002) yang menyatakan bahwa buah belimbing mengandung asam oksalat, asam askorbat, asam formiat, asam sitrat.

\subsection{Analisa Angka Kapang dan Khamir}

Dari analisa yang telah dilakukan jumlah angka kapang dan khamir tertinggi terdapat pada belimbing segar sebesar 20 gram pada bulan ketiga yaitu 354 koloni/gram, sedangkan Jumlah angka kapang dan khamir terendah terdapat pada belimbing segar sebesar 80 gram pada bulan pertama yaitu 1 koloni/gram.

Adapun hubungan pengawet terhadap derajat keasaman $(\mathrm{pH})$ yang tertinggi pada saus sambal dapat dilihat pada grafik 3.3 berikut.

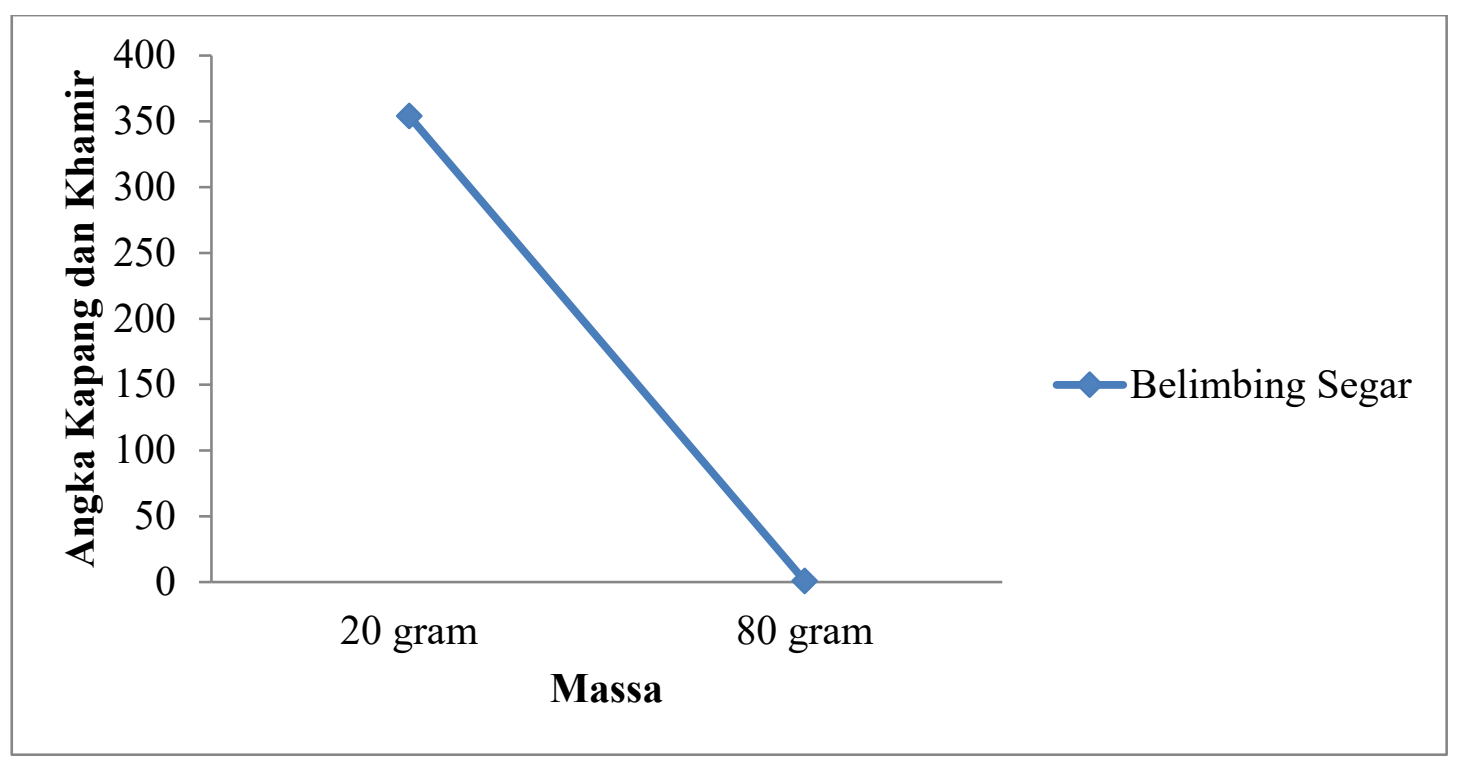

Gambar 3.3 Grafik hubungan angka kapaang dan khamir dengan pengawet buah belimbing

Sehingga dapat disimpulkan untuk pemakaian bahan pengawet menggunakan buah belimbing wuluh, jenis buah belimbing wuluh yang bisa dipakai sebagai bahan pengawet yaitu jenis buah belimbing wuluh kering dengan massa 80 gram, karena jumlah angka kapang dan khamir nya 1 koloni/gram dan cocok digunakan untuk penyimpanan dalam waktu yang lama. Hal ini sesuai dengan syarat mutu saus yang telah diatur dalam Standar Nasional Indonesia nomor SNI 01-3546-2004 yang 
menyatakan jumlah cemaran mikroba yang diperbolehkan dalam pembuatan saus yaitu maksimal $50 \mathrm{koloni} /$ gram. Sehingga untuk cemaran mikroba dalam analisa angka kapang dan khamir dapat disimpulkan semakin sedikit buah belimbing atau semakin banyak labu kuning yang digunakan maka cemaran mikroba saus belimbing akan semakin meningkat. Ini dikarenakan $\mathrm{pH}$ pada labu kuning tinggi dan total asam yang terkandung pada bahan baku rendah sehingga mikroba dapat berkembang biak dengan sangat baik.

Hal ini sesuai dengan pernyataan Winarno dan Jennie (1983) yang menyatakan bahwa pertumbuhan mikroba dipengaruhi oleh beberapa faktor yaitu $\mathrm{AW}$, nilai $\mathrm{pH}$, kandungan gizi dan senyawa antimikroba. Natrium benzoat berperan sebagai antimikroba penghambat kapang dan khamir pada saus.

\section{Simpulan dan Saran}

Buah belimbing wuluh memiliki kandungan asam format sehingga bisa dijadikan sebagai bahan pengawet. Saus sambal yang ditambahkan belimbing kering akan lama awet nya. Itu disebabkan Asam Format lebih banyak terkandung dalam belimbing kering daripada belimbing segar. Berdasarkan analisa umur daya simpan saus sambal, buah belimbing wuluh yang baik dijadikan sebagai bahan pengawet yaitu terdapat pada buah belimbing wuluh kering dengan massa 80 gram, karena pertumbuhan angka kapang dan khamir hanya sebanyak 1 koloni/gr. Jenis pengawet yang memliki kandungan kadar air terbaik terdapat pada buah belimbing wuluh segar dengan massa 80 gram sebesar 49,78\%. Jumlah derajat keasaman $(\mathrm{pH})$ terbaik terdapat pada buah belimbing wuluh segar dengan massa 80 gram yakni 3,21. Tidak ada kerusakan pada saus di bulan pertama baik itu dari jenis pengawet belimbing segar maupun jenis pengawet belimbing kering terhadap angka lempeng total. Faktorfaktor yang mempengaruhi kualitas saus yaitu bahan pembuatan, alat yang digunakan dan proses pengolahan yang menyertai nya. Adapun saran yang didapat dari penelitian yang telah dilakukan adalah, agar dapat memperhatikan sterilisasi dengan benar, supaya saus yang akan dibuat tidak terindikasi dengan cemaran mikroba, sehingga tidak menimbulkan kerusakan pada saus. 


\section{Daftar Pustaka}

1. Ikhsani, A. Y., \& Susanto, W. H. (2015). Pengaruh Proporsi Pasta Labu Kuning Dan Cabai Rawit Serta Organoleptik Saus Labu Kuning Pedas The Effect of Proportion of Pumpkin Paste and Hot Chili with Concentration of Extract Roselle on Physicochemical and Organoleptic of Hot Pumpkin Sauce. 3(2), 499-510.

2. Muzaifa, M. (2004). Perubahan komponen kimia belimbing wuluh (averrhoa bilimb i l.) Selama pembuatan asam sunti.

3. Nafisafallah, F. (2015). Pengaruh penggunaan jenis dan perlakuan cabai yang berbeda terhadap kualitas saus pedas jambu biji merah.

4. Pratiwi, R., Selatan, J. T., \& Yogyakarta, S. U. (2009). Kandungan Saponin Buah, Daun dan Tangkai Daun Belimbing Wuluh (Averrhoa bilimbi L .) The Content of Saponin in Fruits, Leaves and Petioles of Belimbing Wuluh ( Averrhoa bilimbi L .). 220-224.

5. Sitompul, K. R. (2015). Pengaruh perbandingan bubur buah belimbing dengan bubur labu kuning dan konsentrasi natrium benzoat terhadap mutu saus belimbing. 